\title{
Iron in Water: Study of Iron Removal Kinetics in Chemically Reconstituted Waters: Application to Groundwater of South Pout (PS2 Site)
}

\author{
Faye Mamadou ${ }^{*}$, Sambe Falilou Mbacké1, Diop El Hadji Moussa1, Toure Alpha Ousmane ${ }^{1}$, \\ Mbaye Fall Aminata ${ }^{2}$, Diop Mar Codou Guèye ${ }^{1}$ \\ ${ }^{1}$ Laboratory of Electrochemistry and Membrane Process, Ecole Supérieure Polytechnique, Cheikh Anta Diop University, \\ Dakar, Senegal \\ ${ }^{2}$ Quality Control Analysis Laboratory of the Senegalese Water Company (SWC), Dakar, Senegal \\ Email: ^fayeespgc@gmail.com
}

How to cite this paper: Mamadou, F. Mbacké, S.F., El Hadji Moussa, D., Ousmane, T.A., Aminata, M.F. and Guèye, D.M.C. (2021) Iron in Water: Study of Iron Removal Kinetics in Chemically Reconstituted Waters: Application to Groundwater of South Pout (PS2 Site). Open Journal of Metal, 11, 1-10.

https://doi.org/10.4236/ojmetal.2021.111001

Received: September 7, 2020

Accepted: March 21, 2021

Published: March 24, 2021

Copyright $\odot 2021$ by author(s) and Scientific Research Publishing Inc. This work is licensed under the Creative Commons Attribution International License (CC BY 4.0).

http://creativecommons.org/licenses/by/4.0/

\begin{abstract}
The goal of this topic is a synthesis of the main characteristics of iron in groundwater and the oxidation process used to remove it. Indeed, the kinetics of chemical oxidation of iron (II) was examined with reconstituted water (distilled water + iron sulphate) and proceeded to the application in the groundwater samples taken from South Pout (Senegal) precisely in the drilling PS2. The sources of iron are natural or anthropogenic. In Senegalese waters, its content is variable and sometimes exceeds the standards of potability. Despite the diversification of iron removal process, chemical oxidation is the most used solution in drinking water treatment plants in Senegalese rural areas. Applied oxidation processes such as aeration and chlorination, however, are insufficient to produce drinking water with an iron concentration in accordance with standards of potability.
\end{abstract}

Keywords

Iron, Kinetics, Chemical Oxidation, Groundwater, Drilling

\section{Introduction}

In abundance, iron is the fourth element in the Earth's crust and the first among heavy metals [1]. It is found mainly in the form of $\mathrm{Fe}(\mathrm{II})$ or $\mathrm{Fe}$ (III). In reducing medium, as in some groundwater, some lakes or reservoirs, and in the absence of sulphide and carbonate, soluble Fe(II) can be found in high concentration [2]. The presence of iron in natural sources of water supply is attributable to the decomposition of rock and minerals, acidic mine drainage waters, sewage effluent 
and releases from industrial sectors that process iron [3] [4].

In Senegal, the concentration of iron in groundwater is generally less than 10 $\mathrm{mg} \cdot \mathrm{L}^{-1}$. Data obtained from Senegalese Water Company (SWC) between 2000 and 2014 indicate that the concentration varies between less than $0.02 \mathrm{mg} \cdot \mathrm{L}^{-1}$ and $5.76 \mathrm{mg} \cdot \mathrm{L}^{-1}$ in central, southern and eastern areas of Senegal [5].

Iron is an essential part of nutrition; it is included in the composition of cytochromes, porphyrins and metalloenzymes. Iron deficiency, however, may have some effects, including poor mental development and activity in children [6], elevated catecholamine levels, and a tendency for agitation in children [7], loss of work performance in adults and, in severe cases, anemia and compromised oxygenation [8].

It is possible to reduce the excessive amount of iron in groundwater by several conventional techniques including the chemical method. The fundamental principle of the chemical removal of iron is based on an oxidation-reduction reaction between $\mathrm{Fe}^{2+}$ iron and a more or less strong oxidant. The reaction is then the following [9]:

$$
\mathrm{Fe}^{2+}+\text { oxidant } \rightarrow \mathrm{Fe}(\mathrm{OH})_{3(s)}+\text { reducer }
$$

The oxidants used can be oxygen (aeration is then sufficient to remove iron), potassium permanganate, chlorine, chlorine dioxide or ozone. The precipitates formed during the oxidation are then removed by filtration on sand or bilayer medium. In the case of aeration, for example, and therefore of the oxidation of iron by dissolved oxygen, studies have made it possible to determine in kinetic oxidation. The equation is as follows [9]:

$\Rightarrow$ Iron $[10]$ :

$$
-\frac{\mathrm{d}\left[\mathrm{Fe}^{2+}\right]}{\mathrm{d} t}=K \cdot\left[\mathrm{Fe}^{2+}\right] \cdot\left[\mathrm{O}_{2}\right] \cdot\left[\mathrm{OH}^{-}\right]^{2}
$$

which can be simplified in:

$$
-\frac{\mathrm{d}\left[\mathrm{Fe}^{2+}\right]}{\mathrm{d} t}=K_{1} \cdot\left[\mathrm{Fe}^{2+}\right] ; \text { avec } K_{1}=K \cdot\left[\mathrm{O}_{2}\right] \cdot\left[\mathrm{OH}^{-}\right]^{2}
$$

In the present study, the chemical oxidation of iron by various oxidants oxygen $\left(\mathrm{O}_{2}\right)$, potassium permanganate $\left(\mathrm{KMnO}_{4}\right)$, sodium hypochlorite $(\mathrm{NaClO})$ was studied during the treatment of iron-doped water in beakers. The kinetics of chemical oxidation of iron has been examined with reconstituted waters and to determine the kinetics model that describes our experimental results well. The main objective of this paper is to study the iron removal capacity present in groundwater samples in contact with oxidants and even the oxidant with the best treatment rate.

\section{Material and Methods}

\subsection{Methodologies and Material}

Beaker tests are carried out in order to study the oxidation capacities of iron in 
contact with different oxidants with variable $\mathrm{pH}$. The oxidation kinetics of iron is carried out by oxygen, potassium permanganate and finally sodium hypochlorite. For this, a solution of water doped with $5 \mathrm{mg} \cdot \mathrm{L}^{-1} \mathrm{Fe}^{2+}$ is prepared from iron sulphate $\left(\mathrm{FeSO}_{4}\right)$. The amount of oxidant $\left(\mathrm{O}_{2}, \mathrm{KMnO}_{4}, \mathrm{NaClO}\right)$ added is evaluated on the basis of the stoichiometric proportion of the reactions; in this case, $0.73 \mathrm{mg} \mathrm{O}_{2} / \mathrm{L}$ should be bubbled, add $3.61 \mathrm{mg} \mathrm{KMnO}_{4} / \mathrm{L}$ and $2.4 \mathrm{mg} \mathrm{NaClO} / \mathrm{L}$ theoretical masses respectively in each beaker. As a result of these tests, we have moved to the application phase to remove iron from groundwater. The sampling was done in South Pout (Dakar/Senegal) precisely in the drilling PS2 (Figure 1).

The physic and chemical characterization study (Table 1) of the groundwater in South Pout (Senegal) is focused in situ measurements ( $\mathrm{pH}$, electrical conductivity, turbidity) and the laboratory determination of the major components and metallic trace elements (chloride $\mathrm{Cl}^{-}$, sulphates $\mathrm{SO}_{4}^{2-}$, nitrates $\mathrm{NO}_{3}^{-}$, nitrites $\mathrm{NO}_{2}^{-}$, calcium $\mathrm{Ca}^{2+}$, magnesium $\mathrm{Mg}^{2+}$, total iron $\left(\mathrm{Fe}^{2+}\right.$ and $\left.\mathrm{Fe}^{3+}\right)$, manganese $\mathrm{Mg}^{2+}$, etc.).

\subsection{Dosage Protocol}

In order to be in the calibration range, $\left[\mathrm{Fe}^{2+}\right]_{0}<6 \mathrm{mg} \cdot \mathrm{L}^{-1}$, we prepared an initial solution of $4.10^{-5} \mathrm{~mol} \cdot \mathrm{L}^{-1}$ iron sulfate $\left(\mathrm{FeSO}_{4}\right)$ dissolved in distilled water. In 100 $\mathrm{mL}$ volumetric flasks numbered 1 to 7 , put the reagent volumes indicated in the following table, and adjust to the mark with distilled water (Table 2) and (Figure 2).

After adjusting to volume, mix thoroughly and let sit for 5 to 10 minutes. Meanwhile, prepare the reference, and then measure the optical density at 510 $\mathrm{nm}$ relative to the reference solution. Prepare a volumetric flask of $100 \mathrm{~mL}$ of the

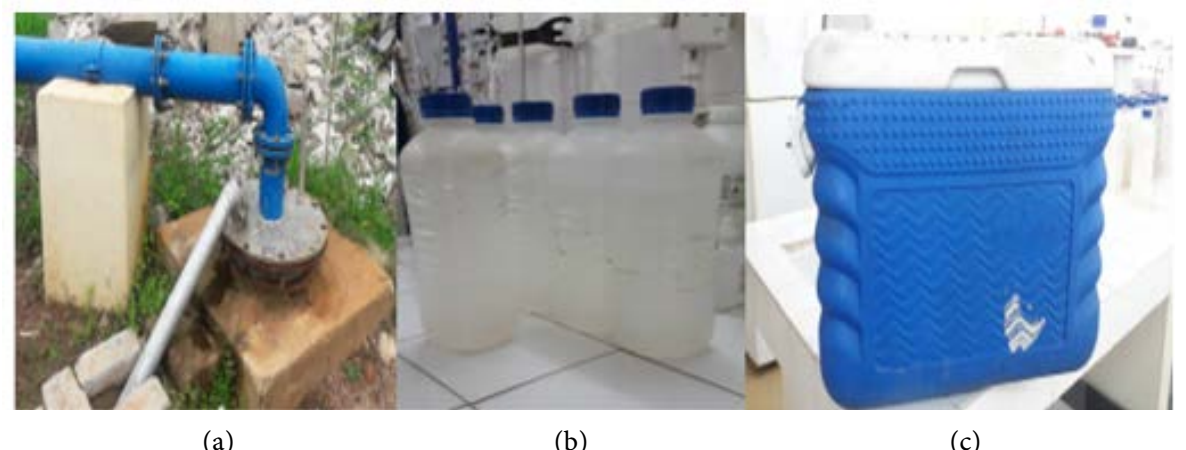

(a)

(b)

(c)

Figure 1. (a) South pout drilling (PS2); (b) Polyethylene bottles; (c) Cooler at $4{ }^{\circ} \mathrm{C}$.

Table 1. Physic and chemical characterization of groundwater in South Pout (Senegal).

South Pout (PS2 Site)

\begin{tabular}{cccccccccccc}
\hline \multicolumn{10}{c}{ Tablecloth Captured: Maestrichtian } & & \\
\hline Parameters & $\begin{array}{c}\text { Cond } \\
\mu \mathrm{s} \cdot \mathrm{cm}^{-1}\end{array}$ & $\mathrm{pH}$ & Turb NTU & $\mathrm{Cl}^{-\circ} \mathrm{F}$ & $\begin{array}{c}\mathrm{SO}_{4}^{2-} \\
\mathrm{mg} \cdot \mathrm{L}^{-1}\end{array}$ & $\mathrm{Ca}^{2+}{ }^{\circ} \mathrm{F}$ & $\mathrm{Mg}^{2+}{ }^{\circ} \mathrm{F}$ & $\begin{array}{c}\mathrm{NO}_{3}^{-} \\
\mathrm{mg} \cdot \mathrm{L}^{-1}\end{array}$ & $\begin{array}{c}\mathrm{NO}_{2}^{-} \\
\mathrm{mg} \cdot \mathrm{L}^{-1}\end{array}$ & $\begin{array}{c}\mathrm{Fer} \mathrm{total} \\
\mathrm{mg} \cdot \mathrm{L}^{-1}\end{array}$ & $\begin{array}{c}\mathrm{Mn}^{2+} \\
\mathrm{mg} \cdot \mathrm{L}^{-1}\end{array}$ \\
\hline Value & 567 & 7.01 & 13.40 & 3.00 & 5.00 & 5.60 & 21.60 & 0.60 & 0.004 & 5.76 & 0.054 \\
\hline
\end{tabular}


Table 2. Preparation of solutions for the calibration curve.

\begin{tabular}{|c|c|c|c|c|}
\hline $\begin{array}{c}\text { Initial } \\
\text { solution }(\mathrm{mL})\end{array}$ & $\begin{array}{l}\text { Hydroxylammonium } \\
\text { chloride } 10 \%(\mathrm{~mL})\end{array}$ & $\begin{array}{l}\text { Sodium } \\
\text { acetate } 2 \mathrm{M} \\
\quad(\mathrm{mL})\end{array}$ & $\begin{array}{c}\text { Ortho-Phenanthroline } \\
0.25 \%(\mathrm{~mL})\end{array}$ & $\begin{array}{l}\text { Final concentration } \\
{\left[\mathrm{Fe}^{2+}\right]\left(\text { mole } \cdot \mathrm{L}^{-1}\right)}\end{array}$ \\
\hline 1 & 10 & 1 & 8 & $4 \times 10^{-7}$ \\
\hline 2 & 10 & 2 & 8 & $8 \times 10^{-7}$ \\
\hline 3 & 10 & 3 & 8 & $1.2 \times 10^{-6}$ \\
\hline 4 & 10 & 4 & 8 & $1.6 \times 10^{-6}$ \\
\hline 5 & 10 & 5 & 8 & $2 \times 10^{-6}$ \\
\hline 6 & 10 & 6 & 8 & $2.4 \times 10^{-6}$ \\
\hline 7 & 10 & 7 & 8 & $2.8 \times 10^{-6}$ \\
\hline
\end{tabular}

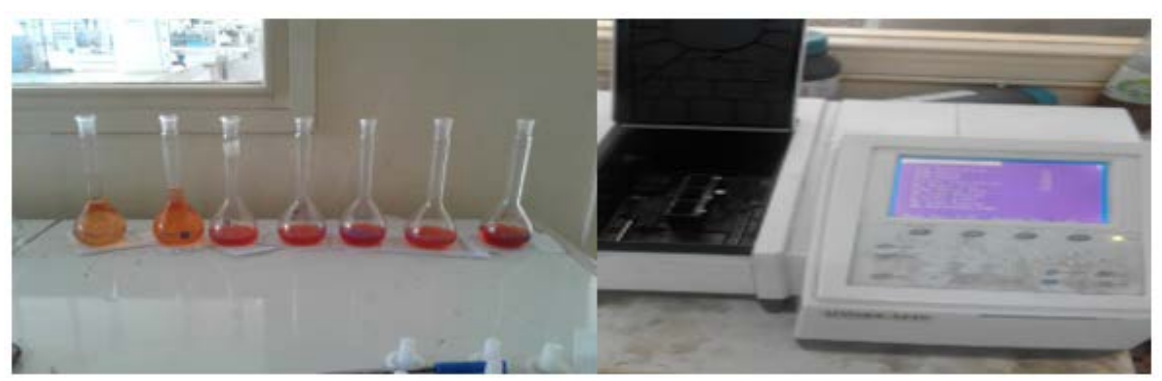

(a)

(b)

Figure 2. (a) Preparation of the calibration range; (b) UV-Visible spectrophotometer.

reference solution by pouring $10 \mathrm{~mL}$ of methylene chloride of $10 \%$ hydroxylammonium, $5 \mathrm{~mL}$ of $2 \mathrm{M}$ sodium acetate, $8 \mathrm{~mL}$ of ortho-phenanthroline $0.25 \%$ and make up to gauge with distilled water (Figure 2).

\subsection{Oxidation of Iron (II)}

The principle is to dissolve the theoretical mass of the oxidant $\left(\mathrm{O}_{2}, \mathrm{KMnO}_{4}\right.$, $\mathrm{NaClO}$ ) in the already known concentration of the iron (II) solution, while checking the $\mathrm{pH}$ and temperature, allowing the oxidation reaction to proceed with thorough agitation of the reaction medium (Figure 3). At the end of each operation, the precipitates deposited at the bottom of the beaker before proceeding to the spectrometric determination of the mixture are filtered. The oxidation reactions are summarized as following:

$$
\begin{gathered}
4 \mathrm{Fe}^{2+}+\mathrm{O}_{2}+10 \mathrm{H}_{2} \mathrm{O} \rightarrow 4 \mathrm{Fe}(\mathrm{OH})_{3(\mathrm{~s})}+8 \mathrm{H}^{+} \\
3 \mathrm{Fe}^{2+}+\mathrm{MnO}_{4}^{-}+2 \mathrm{H}_{2} \mathrm{O}+5 \mathrm{OH}^{-} \rightarrow 3 \mathrm{Fe}(\mathrm{OH})_{3(\mathrm{~s})}+\mathrm{MnO}_{2(\mathrm{~s})} \\
2 \mathrm{Fe}^{2+}+\mathrm{HClO}+5 \mathrm{H}_{2} \mathrm{O} \rightarrow 2 \mathrm{Fe}(\mathrm{OH})_{3(\mathrm{~s})}+\mathrm{Cl}^{-}+5 \mathrm{H}^{+}
\end{gathered}
$$

\section{Results and Discussion}

\subsection{Iron Calibration Curve}

The calibration curve is then obtained from the measurement of the absorbance of each standard solution (Figure 4). 


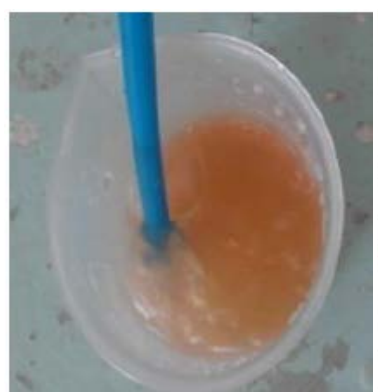

(a)

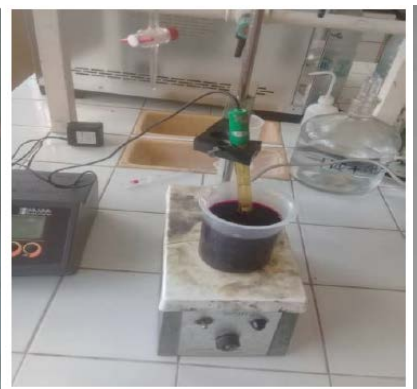

(b)

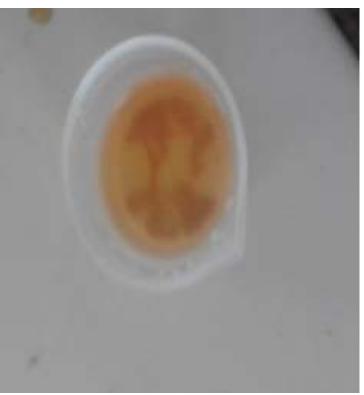

(c)

Figure 3. (a) Oxidation of iron by Oxygen $\left(\mathrm{O}_{2}\right)$; (b) Oxidation of iron by potassium permanganate $\left(\mathrm{KMnO}_{4}\right)$; (c) Oxidation of iron by sodium hypochlorite $(\mathrm{NaClO}) ;\left(\left[\mathrm{Fe}^{2+}\right]_{0}=\right.$ $5 \mathrm{mg} \cdot \mathrm{L}^{-1}, \mathrm{P}_{\mathrm{atm}}=1.013$ bar and $\left.\mathrm{T}=21^{\circ} \mathrm{C} \pm 1^{\circ} \mathrm{C}\right)$.

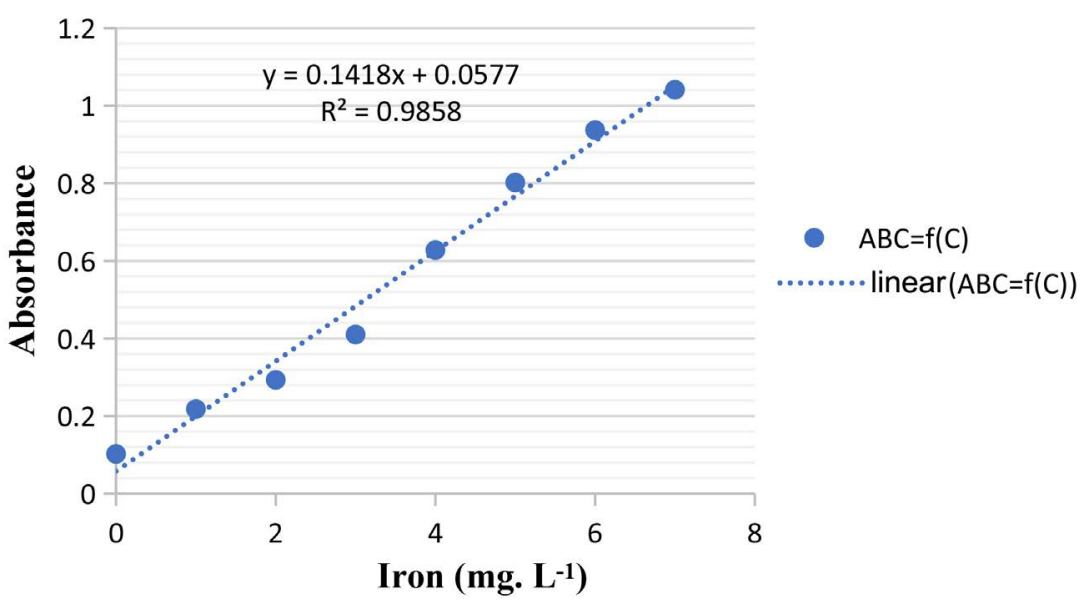

Figure 4. Calibration curve of the absorbance of the solution as function of concentration.

The concentration of the sample taken is calculated by multiplying by 10 the concentration obtained (to take into account the dilution factor). The corresponding iron concentration is calculated from the following relation:

$$
\left[\mathrm{Fe}^{2+}\right]_{\text {total }}=\frac{\mathrm{ABS}-0.0577}{0.1418}
$$

\subsection{Oxidation Kinetics}

A series of tests in beaker is carried out in order to verify the kinetics of oxidation of iron by different oxidants as a function of the $\mathrm{pH}$. For this, the $\mathrm{pH}$ of the water is adjusted by concentrated hydrochloric acid $(\mathrm{HCl})$ and sodium hydroxide $(\mathrm{NaOH})$ solutions. The results obtained for each of the oxidants used are shown in Figures 5-7.

$\mathrm{Fe}^{2+}$ oxidation tests in beaker are carried out at three different $\mathrm{pH}$ ranges, $\mathrm{pH}$ $=3.4-3.6 ; \mathrm{pH}=7.3-7.5$ and $\mathrm{pH}=9.8$ - 10. Indeed, for Figure 5, the results show that at $\mathrm{pH}=9.8$ in less than five minutes, $95 \%$ of ferrous iron $\left(\mathrm{Fe}^{2+}\right)$ is removed whereas at $\mathrm{pH}=7.3$, only $60 \%$ of ferrous iron has disappeared. In the other hand, at acid $\mathrm{pH}$, there is no removal of iron, and then iron is not oxidized by 


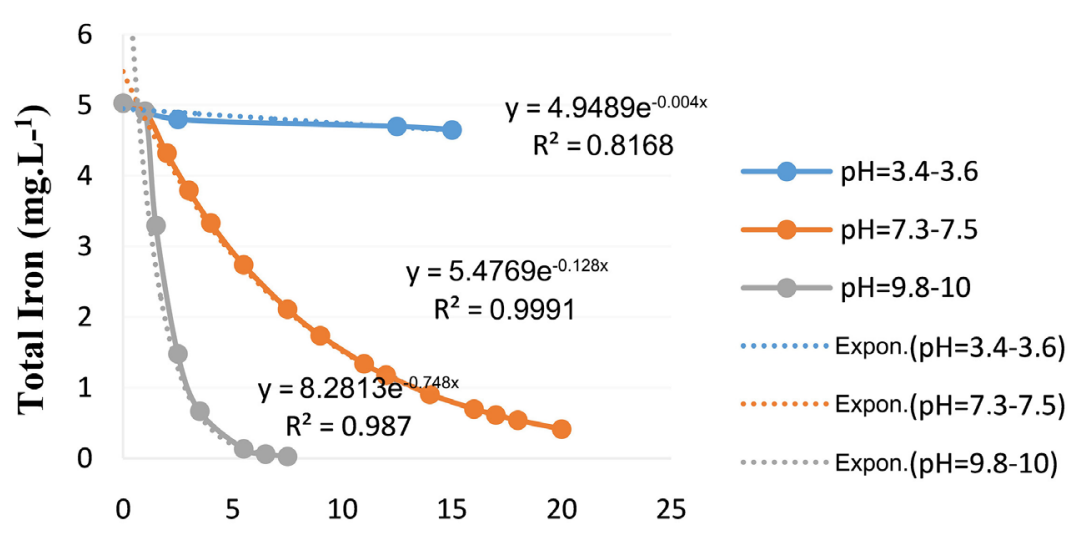

Time (minutes)

Figure 5. Kinetics oxidation of iron by oxygen $\left(\mathrm{O}_{2}\right)$ at different $\mathrm{pH}$; $\left(\left[\mathrm{Fe}^{2+}\right]_{0}=5 \mathrm{mg} \cdot \mathrm{L}^{-1}\right.$, $\mathrm{P}_{\mathrm{atm}}=1.013 \mathrm{bar}, \mathrm{T}=21^{\circ} \mathrm{C} \pm 1^{\circ} \mathrm{C}$ and redox potential $=300 \mathrm{mV}$ ).

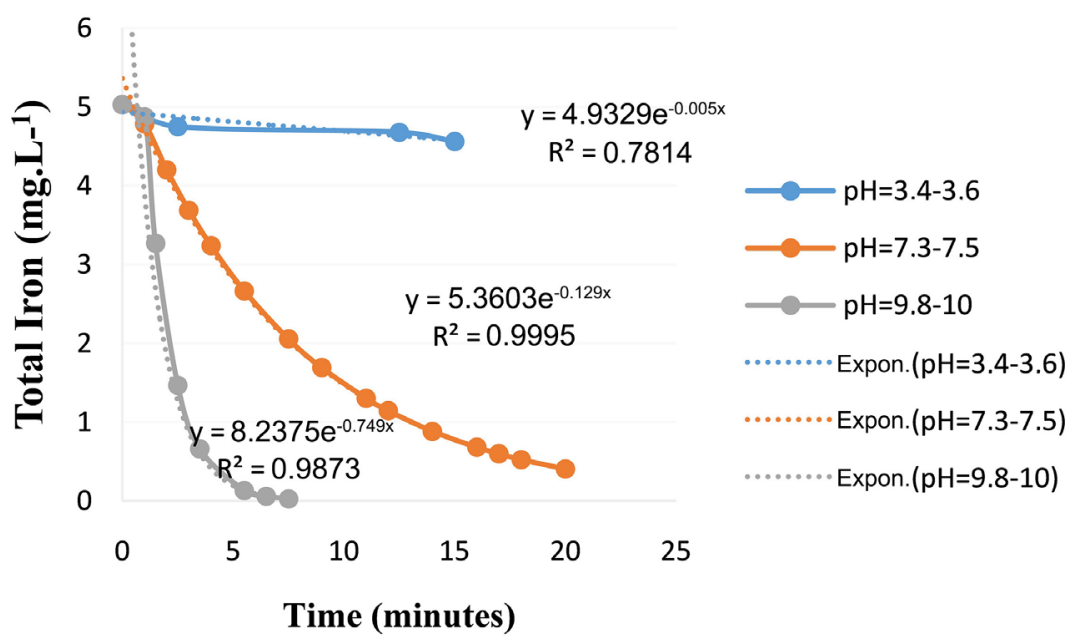

Figure 6. Kinetics of iron oxidation by potassium permanganate $\left(\mathrm{KMnO}_{4}\right)$ at different $\mathrm{pH} ;\left(\left[\mathrm{Fe}^{2+}\right]_{0}=5 \mathrm{mg} \cdot \mathrm{L}^{-1}, \mathrm{P}_{\mathrm{atm}}=1.013 \mathrm{bar}, \mathrm{T}=21^{\circ} \mathrm{C} \pm 1^{\circ} \mathrm{C}\right.$ and redox potential $\left.=300 \mathrm{mV}\right)$.

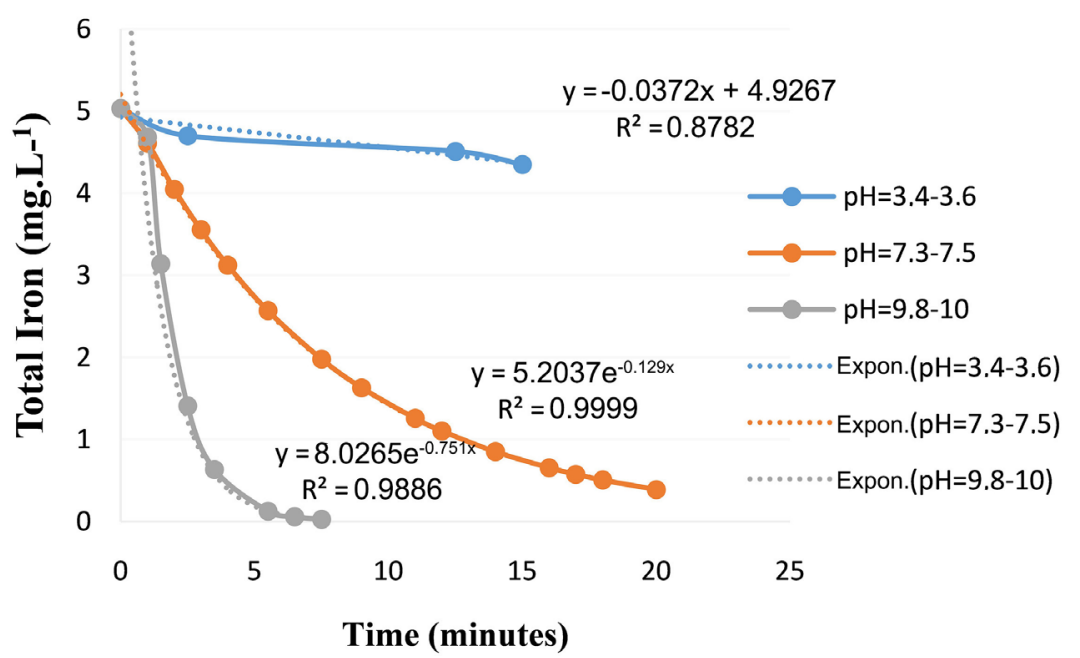

Figure 7. Kinetics of iron oxidation by sodium hypochlorite $(\mathrm{NaClO})$ at different $\mathrm{pH}$; $\left(\left[\mathrm{Fe}^{2+}\right]_{0}=5 \mathrm{mg} \cdot \mathrm{L}^{-1}, \mathrm{P}_{\text {atm }}=1.013 \mathrm{bar}, \mathrm{T}=21^{\circ} \mathrm{C} \pm 1^{\circ} \mathrm{C}\right.$ and redox potential $\left.=300 \mathrm{mV}\right)$. 
oxygen at acidic $\mathrm{pH}$. Depending on the $\mathrm{pH}$ of the water, the kinetics will be more or less rapid. It is possible to find the order of the kinetics by applying a trend line to the curves determined experimentally (here the exponential type allows to find an order line). This kinetics can therefore be modeled as follows:

$$
-\frac{\mathrm{d}\left[\mathrm{Fe}^{2+}\right]}{\mathrm{d} t}=K t
$$

These results are consistent with the results obtained by [11] [12] which showed that, in the presence of iron, a significant fraction of the iron can be oxidized by $\mathrm{O}_{2}$ and at a relatively basic $\mathrm{pH}$ (Figure 5).

Beaker tests were also carried out with potassium permanganate $\left(\mathrm{KMnO}_{4}\right)$ as oxidant at different $\mathrm{pH}$. The kinetics of oxidation of dissolved iron is reported in the graph of Figure 6 . The results show that at $\mathrm{pH}=9.85$ in less than five minutes, $96.85 \%$ of ferrous iron $\left(\mathrm{Fe}^{2+}\right)$ is removed while at $\mathrm{pH}=7.5$, only $63 \%$ of the ferrous iron is removed. In the same way, at acidic $\mathrm{pH}$, the removal of iron is very weak or even non-existent. The kinetics of chemical oxidation of experimental values is written by the kinetic model of the equation above. These results are consistent with the work of some authors [11] [12] who showed that, in the presence of iron, a significant fraction of iron can be oxidized by $\mathrm{KMnO}_{4}$ as well.

With regard to the removal of ferrous iron by sodium hypochlorite $(\mathrm{NaClO})$ at different $\mathrm{pH}$, the dissolved iron disappears after five minutes which is consistent with the work of KNOCKE et al., (1990a) who showed that the oxidation kinetics of $\mathrm{Fe}^{2+}$ by $\mathrm{NaClO}$ was very fast. The results (Figure 7) show that at $\mathrm{pH}=$ 9.8 in less than five minutes, $98.25 \%$ ferrous iron $\left(\mathrm{Fe}^{2+}\right)$ is removed and has the most effective oxidant. The theoretical stoichiometric dose of $\mathrm{NaClO}$ is therefore too much to eliminate iron. Hence the possibility of the theoretical quantity being put in contact with the sample reduces by $1 / 3$.

\subsection{Removal of Iron in the Waters of South Pout (PS2 Site)}

The oxidation capacity makes it possible to find the maximum amount of iron that the oxidant is capable of reducing $\mathrm{Fe}^{2+}$ ions to $\mathrm{Fe}^{3+}$. To find the oxidation capacities, groundwater samples of $5.403 \mathrm{mg} \mathrm{Fe}^{2+} / \mathrm{L}$ with an initial $\mathrm{pH}$ of 7.01 are regulated at $\mathrm{pH}=9.8$. In three $100 \mathrm{~mL}$ beakers, we put $30 \mathrm{~mL}$ of the sample plus the calculated theoretical oxidant mass. This suspension is placed in a rotary shaker for 5 minutes so that the maximum oxidation capacity of the iron is reached. The results of this experiment make it possible to calculate the percentage of iron eliminated by the various oxidants. They are presented in Table 3.

The results presented above make it possible to evaluate the treatment efficiency of the three oxidants used for the removal of iron (II) in groundwater of South Pout (PS2 site).

We recorded a percentage of iron removed of $93.74 \%$ for the use of oxygen as oxidant. Indeed, the iron is very unstable in the water in the presence of oxygen as seen on the diagram of Pourbaix of the iron [13], which is why the removal of 
Table 3. Chemical oxidation of groundwater of South Pout (PS2 site).

\begin{tabular}{|c|c|c|c|c|c|}
\hline $\begin{array}{c}\text { V } \\
\text { sample }(\mathrm{mL})\end{array}$ & $\begin{array}{c}\text { Oxidizing } \\
\text { mass } \\
(\mathrm{mg})\end{array}$ & $\begin{array}{l}\text { Contact time } \\
\text { (minutes) }\end{array}$ & $\begin{array}{l}\text { Measured initial } \\
\text { concentration } \\
\left(\mathrm{mg} \cdot \mathrm{L}^{-1}\right)\end{array}$ & $\begin{array}{l}\text { Final measured } \\
\text { concentration } \\
\left(\mathrm{mg} \cdot \mathrm{L}^{-1}\right)\end{array}$ & $\begin{array}{l}\% \text { of Total } \\
\text { Iron elimi- } \\
\text { nated }\end{array}$ \\
\hline \multicolumn{6}{|c|}{ Oxygen $\left(\mathrm{O}_{2}\right)$ at $\mathrm{pH}=9.8$} \\
\hline 30 & 0.73 & 5 & 5.403 & 0.321 & 93.74 \\
\hline \multicolumn{6}{|c|}{ Potassium permanganate $\left(\mathrm{KMnO}_{4}\right)$ at $\mathrm{pH}=9.8$} \\
\hline 30 & 3.61 & 5 & 5.403 & 0.285 & 94.43 \\
\hline \multicolumn{6}{|c|}{ Sodium hypochlorite $(\mathrm{NaClO})$ at $\mathrm{pH}=9.8$} \\
\hline 30 & 2.4 & 5 & 5.403 & 0.205 & 96.01 \\
\hline
\end{tabular}

this element in presence only of aerated water $(9.5 \mathrm{mg} \mathrm{O} / \mathrm{L})$ is very fast unless the $\mathrm{pH}$ of the water is basic $(\mathrm{pH}=9.8)$. A second oxidant is then tested, potassium permanganate, oxidizing stronger than oxygen. For this experiment, the stoichiometric dose is respected, i.e. a dose of $3.61 \mathrm{mg} \mathrm{KMnO}_{4} / \mathrm{L}$ starting from a theoretical initial concentration of $\mathrm{Fe}^{2+}$ of $5 \mathrm{mg} / \mathrm{L}$. Potassium permanganate is a very strong oxidizer that achieves the almost complete oxidation of soluble iron almost instantaneously. Indeed, the results show that after one minute of experience, $85 \%$ of the soluble iron in groundwater is removed at $\mathrm{pH}=9.8$. This oxidant seems to be the most suitable for the removal of $\mathrm{Mn}^{2+}$, however, it should not be introduced in excess under penalty of a pink coloration of the samples. It is therefore necessary to dose it well so that it is present in order to only remove the soluble iron present in the water to be treated. The results show that the most efficient oxidant is sodium hypochlorite $(\mathrm{NaClO})$, with a percentage of iron eliminated by $96 \%$ under the conditions of these tests. These results confirm the kinetics of iron oxidation by sodium hypochlorite $(\mathrm{NaClO})$.

The advantage of these three systems is the need for a single filtration stage. By comparing them with each of the systems, it can be seen that the difference in the percentage of iron eliminated is relatively small. The difference is on average $1.58 \%$, which could guide the choice of the type of oxidant to use. From the economic point of view, the use of oxygen as an oxidant would result in a lower investment cost compared to potassium permanganate $\left(\mathrm{KMnO}_{4}\right)$ or sodium hypochlorite $(\mathrm{NaClO})$ because it is sufficient to air ventilate to reduce $\mathrm{Fe}^{2+}$.

\section{Conclusions}

Three oxidants, two of which were marketed for their potential iron (II) removal, were tested in this topic: oxygen $\left(\mathrm{O}_{2}\right)$, potassium permanganate $\left(\mathrm{KMnO}_{4}\right)$, sodium hypochlorite $(\mathrm{NaClO})$. The batch tests (solution of water doped with 5 $\mathrm{mg} \mathrm{Fe} e^{2+} / \mathrm{L}$ prepared from iron sulphate $\left(\mathrm{FeSO}_{4}\right)$ ) bring out the following results:

- iron removal efficiency increases with $\mathrm{pH}$;

- the kinetics of chemical oxidation of the iron of our experimental results is of exponential type which allows to find a one (1) order;

- under the conditions of these tests, the results of sodium hypochlorite ( $\mathrm{NaClO})$ 
show that at $\mathrm{pH}=9.8$ in less than five minutes, $98.25 \%$ of ferrous iron $\left(\mathrm{Fe}^{2+}\right)$ is removed and presents the most effective oxidant.

The tests carried out on the groundwater of South Pout (Dakar/Senegal) precisely on PS2 drilling to remove iron give the following main results:

- results similar to those obtained in batch iron solutions prepared in terms of percentage of removal. Batch tests on reconstituted water are therefore recommended to study the kinetics of oxidation;

- iron is rapidly oxidized by dissolved oxygen $\left(\mathrm{O}_{2}\right)$ when the $\mathrm{pH}$ is adjusted to 9.8, and therefore it is not necessary to use potassium permanganate $\left(\mathrm{KMnO}_{4}\right)$ or sodium hypochlorite $(\mathrm{NaClO})$ to oxidize it. This is justified by high economic costs related to the chemical implementation of the process using $\mathrm{KMnO}_{4}$ or $\mathrm{NaClO}$ as oxidant compared with $\mathrm{O}_{2}$;

- the results show that the most efficient oxidant is sodium hypochlorite $(\mathrm{NaClO})$, with a percentage of iron removed by $96 \%$ under the conditions of these tests on groundwater of PS2. These results confirm the kinetics of iron oxidation by sodium hypochlorite $(\mathrm{NaClO})$.

In the economic approach, the use of oxygen as an oxidant would result in a lower investment and exploitation cost compared to potassium permanganate or sodium hypochlorite because a simple aeration is enough to reduce the dissolved iron.

\section{Conflicts of Interest}

The authors declare no conflicts of interest regarding the publication of this paper.

\section{References}

[1] Belghiti, M., Chahlaoui, A., Bengoumi, D. and El Moustaine, R. (2013) Etude de la qualité physico-chimique et bactériologique des eaux souterraines de la nappe plio-quaternaire dans la région de Meknès (Maroc). LARHYSS Journal P-ISSN 1112-3680/E-ISSN 2602-7828.

[2] Johnson, C.D., Nandi, A., Joyner, T.A. and Luffman, I. (2018) Iron and Manganese in Groundwater: Using Kriging and GIS to Locate High Concentrations in Buncombe County, North Carolina. Groundwater, 56, 87-95. https://doi.org/10.1111/gwat.12560

[3] Makhatova, A. (2019) Photochemical Treatment of Wastewaters. Nazarbayev University School of Engineering.

[4] Odum, H.T. (2016) Heavy Metals in the Environment: Using Wetlands for Their Removal. CRC Press, Boca Raton. https://doi.org/10.1201/9781420032840

[5] Senegalese Water Company (2014) Rapport sur l'évaluation des paramètres physico-chimiques des eaux souterraines sénégalaises. ANSD, 54.

[6] Andrews, N.C. (2000) Iron Metabolism: Iron Deficiency and Iron Overload. Annual Review of Genomics and Human Genetics, 1, 75-98. https://doi.org/10.1146/annurev.genom.1.1.75

[7] Bianco, L., Unger, E. and Beard, J. (2009) Iron Deficiency and Neuropharmacology, Iron Deficiency and Overload. Springer, Berlin, 141-158. 
https://doi.org/10.1007/978-1-59745-462-9_8

[8] Callahan, L.A., Woods, K.F., Mensah, G.A., Ramsey, L.T., Barbeau, P. and Gutin, B. (2002) Cardiopulmonary Responses to Exercise in Women with Sickle Cell Anemia. American Journal of Respiratory and Critical Care Medicine, 165, 1309-1316. https://doi.org/10.1164/rccm.2002036

[9] Charles, P. (2006) Elimination catalytique du fer et du manganèse pour la production d'eau potable. Rapport, 60.

[10] Stumm, W. and Lee, G.F. (1961) Oxygenation of Ferrous Iron. Industrial \& Engineering Chemistry, 53, 143-146. https://doi.org/10.1021/ie50614a030

[11] Achour, S., Tibermacine, A. and Chabbi, F. (2017) Iron and Manganese in Natural Waters and Chemical Oxidation Methods. Case of Algerian Waters. Larhyss Journal, 139-154.

[12] Coffey, B.M. (1990) Removal of Soluble Iron and Manganese from Groundwater by Chemical Oxidation and Oxide-Coated Multi-Media Filtration. Virginia Tech.

[13] Zegeye, A. (2006) Formation et stabilité des hydroxysels Fe(II-III) de type rouille verte en cultures bactériennes. Nancy 1 . 